\title{
1980 styczeń-czerwiec, red. Piotr Długołęcki, Polski Instytut Spraw Międzynarodowych, Warszawa 2018 (Polskie Dokumenty Dyplomatyczne, 25), LXXIV + 1048 ss.
}

Wydawana przez Polski Instytut Spraw Międzynarodowych (PISM) seria „Polskie Dokumenty Dyplomatyczne” (PDD) powiększyła się o kolejny, dwudziesty piąty już tom, obejmujący pierwszą połowę 1980 r. Kierunki, priorytety i problemy polskiej polityki zagranicznej tego okresu zostały ukazane w 513 dokumentach pochodzących głównie z Archiwum Ministerstwa Spraw Zagranicznych i Archiwum Akt Nowych w Warszawie.

W pierwszych sześciu miesiącach 1980 r. scena międzynarodowa w dużej mierze ukształtowana była przez wypadki z grudnia roku poprzedniego, tj. podjęcie przez państwa NATO podwójnej uchwały o rozmieszczeniu w Europie Zachodniej rakiet średniego zasięgu z głowicami nuklearnymi, a także wkroczenie wojsk radzieckich do Afganistanu kilka dni później. Tym samym dobiegł końca okres détente, czego jednym z symboli było podpisanie w 1975 r. w Helsinkach Aktu końcowego Konferencji Bezpieczeństwa $i$ Wspótpracy w Europie.

Polska jako członek bloku socjalistycznego występowała na arenie międzynarodowej w roli adwokata ZSRR w sprawie Afganistanu. W styczniu stały przedstawiciel przy ONZ Henryk Jaroszek wygłosił na forum Zgromadzenia Ogólnego ostre przemówienie, które retorycznie bardziej odpowiadało czasom stalinowskim niż okresowi odprężenia (dok. 41). Należy przy tym zauważyć, że nie wszystkie państwa bloku popierały radziecką akcję. Spotkała się ona np. z krytyką kierownictwa Rumuńskiej Partii Komunistycznej, o czym donoszono w szyfrogramach słanych do Warszawy (dok. 44). Nicolae Ceaușescu uważał, że „wejście wojsk radzieckich pozwoliło USA podjąć kampanię przeciwko ZSRR i doprowadziło do izolacji KS [krajów socjalistycznych - M.F.]”, dlatego też „należy zrobić wszystko w celu wycofania wojsk radzieckich z Afganistanu" (dok. 407). 
Wiele dokumentów poświęconych jest sprawom gospodarczym, co wynikało z bardzo ciężkiego położenia ekonomicznego PRL i rozpaczliwego poszukiwania zagranicznych kredytów. Jak zauważono we wstępie do tomu, sytuacja ta „ograniczała możliwość realizacji celów politycznych”. Należy jednak pamiętać, że o ile Polska często występowała w roli państwa ubiegającego się o pomoc, to w licznych przypadkach była również adresatem podobnych próśb (najczęściej o zapomogę finansową lub materialną), których nadawcami były m.in. Wietnam (dok. 322), Nikaragua (dok. 326) czy Gwinea (dok. 49 - prośba o kilka tysięcy sztuk pochodni ,potrzebnych dla zorganizowania nocnego marszu rewolucyjnego").

Strona polska próbowała jednocześnie podtrzymywać i inicjować dialog na linii Wschód-Zachód. Placówki promowały w tym celu koncepcję zwołania w Warszawie konferencji w sprawie odprężenia militarnego i rozbrojenia (od początku jednak skazaną na niepowodzenie) czy organizację w Wilanowie spotkania sekretarza generalnego KPZR Leonida Breżniewa z prezydentem Francji Valérym Giscardem d'Estaing przy udziale Edwarda Gierka (dok. 340, 436, 449). Należy jednak podkreślić, że mimo usilnych zabiegów prócz wątpliwych efektów prestiżowych nie przyniosły one wymiernych rezultatów.

Publikowane $\mathrm{w}$ tym tomie dokumenty poruszają ponadto m.in. takie zagadnienia, jak stosunki ze Stolicą Apostolską (sprawa wydawania polskojęzycznej wersji pisma „L'Osservatore Romano”), relacje z państwami niemieckimi (m.in. procesy zbrodniarzy wojennych w RFN), organizacja wyborów do Sejmu w punktach zagranicznych czy bezpieczeństwo placówek (m.in. w Luandzie, Kabulu i Malmö). Ważne miejsce zajmują w nim również sprawy konsularne, w tym proceder fałszowania paszportów w Stanach Zjednoczonych (dok. 143). Część dokumentów dotyczy przygotowań do lipcowych igrzysk olimpijskich w Moskwie, bojkotowanych przez USA i ich sojuszników (dok. 22, 123, 140, 269, 433, 437, 446).

Na pierwszą połowę 1980 r. przypadało też kilka istotnych rocznic: zakończenia drugiej wojny światowej, powstania Układu Warszawskiego (dok. 407), ale także zbrodni katyńskiej. Szereg inicjatyw w związku z tą ostatnią podjęły prężne środowiska polonijne w Stanach Zjednoczonych, Kanadzie i Wielkiej Brytanii (dok. 276, 331, 333, 350, 352, 369 i 373). Polskie placówki zagraniczne - zgodnie z instrukcjami otrzymywanymi z centrali - szczególnie uważnie śledziły uroczystości związane z Rokiem Katynia, m.in. przeciwdziałając (wspólnie z ZSRR) uczestnictwu w tych obchodach przedstawicieli władz danego kraju czy organizując w tym czasie szereg imprez dla Polonii (dok. 276). 
Wiele dokumentów opatrzonych zostało przypisami, które stanowią dopełnienie tekstu właściwego i pomagają uchwycić kontekst opisywanych wydarzeń. Lekturę tomu ułatwiają rozbudowane indeksy - rzeczowy i osobowy - a także wstęp, w którym zawarto m.in. opis struktury MSZ (podparty schematem zamieszczonym $\mathrm{w}$ aneksie $\mathrm{nr}$ II) oraz szczegółowe informacje dotyczące wyboru i edycji źródeł. 